\title{
Customer Loyalty in Telecom Sector of Pakistan
}

\author{
Amna Nasir \\ Department of Management Sciences, The Islamia University of Bahawalpur, Pakistan
}

Hamna Mushtaq

Department of Management Sciences, The Islamia University of Bahawalpur, Pakistan

Muhammad Rizwan (Corresponding author)

Lecturer, Department of Management Sciences,

The Islamia University of Bahawalpur, Pakistan

E-mail: rizwan.arshad@iub.edu.pk

Doi:10.5296/ jsr.v5i1.6575 URL: http://dx.doi.org/10.5296/ jsr.v5i1.6575

\begin{abstract}
This study examines major influences on customer loyalty in a research framework where customer loyalty is the dependent variable and customer satisfaction, perceived price, service quality and trust are all independent variables. The research also tests the hypothesis that there exists a moderating relationship between service quality and customer satisfaction. The study employs various statistical techniques, including reliability, factor and regression analysis. The epistemology of research was primarily qualitative and involved 170 citizens of Pakistan through a questionnaire led survey and factor analysis was further applied to confirm the results. This study acknowledges service quality positively affecting customer satisfaction with perceived price acting as a moderating variable. In addition to that service quality also has a significant positive influence on trust. Customer satisfaction is a strong variable effecting customer loyalty and trust positively. Therefore it could be postulated that customers with high rated perception of service quality and satisfaction also generally exhibit repurchase intent and strong loyalty towards the products. Furthermore, the study also adds up that the moderating variables positively influence the relationship. Increase in the customer's perception on the reasonableness of price also tends to increase the impact of service quality on customer satisfaction.
\end{abstract}

Keywords: Customer Loyalty, Customer needs, Market, Telecom sector 


\section{Introduction}

The ability to attract the right target market, making them buy/consume the product on a regular basis and in high quantities and advocating for the product enabling more customers to shift from the substitute products to your product is termed as Customer loyalty. It is often described as the ability to generate repeat orders from the customers and securing good ratings and reviews. This in turn results in increase in the customer base for the company as more customers shift towards the company's products as a result of word of mouth publicity from the existing customers. However the term is not just confined to this as it is a continuous approach or program managed by the company directed towards keeping its customers happy so that they in turn bring more business for the company.

The business can ensure maximized profits through happy and loyal customers by providing firm guarantee with good quality products. Out of the numerous ways of achieving customer loyalty few are through free offers, gift coupons, competitively low interest rates, trade-ins for better value, extended warranties, rebates, and other rewards programs. Whatever be the mechanism the ultimate objective remains expanding the customer base by adding more customers that through their word of mouth publicity and reviews helps the company in meeting the objective of increased profitability and having and retaining happy customers.

There are many popular programs to entice customers towards a brand, some of which include giving away free gifts with the products or allowing rebates to the customers or by one get one free schemes. The company may also offer a risk free trial period to the customers to try their products, also termed as brand name loyalty, the objective of all these schemes are to induce the customer to not only buy the company's product again and again but to also motivate them to try more variety of items from the company's portfolio of products and services. Another tool for winning loyal customers is to provide excellent customer and after sales service. A company focused on increasing customer loyalty should make an allowance for product claims and after sales service as excellent customer service is an essential for creating and maintaining customer loyalty. This requires the company to take every possible measure while remaining in its budgeted cost allowance to respond to the customer complains in respect of the goods sold and replaces the goods that are faulty or to make full refunds incase the customers are not happy with the quality of goods.

For every business new or established retaining its existing customers has always been less cost effective that making new customers, Existing customers not only ensure the achievement of existing level of sales but are also more responsive to any ancillary or supplemental products that are introduced by the company. Existing customers who are loyal to the company's products are an effective element in keeping the consumer education and marketing costs below the expected levels. Many companies consider the customer experience programs as an effective tool to differentiate themselves from the competitors. This differentiation helps in generating and developing customer loyalty through their behavioral, cultural and intellectual association with the product, either during or after the use. Customer management also provides a sustainable competitive advantage to the companies focusing on customer loyalty. This study highlights various variables, their impact and their 
link with customer loyalty. These can be categorized in to service quality, trust, customer satisfaction and perceived price.

Service quality is a term that has been elaborated and explained through many definitions. However it's an accepted and learned fact that higher service quality can only be defined by the customers resulting from provision of services by an organization that satisfies the customer's needs and expectations (Metters et al., 2003). Thus, service quality can simply be defined as the fulfillment of customer expectations. Conceptual and empirical studies suggest that service quality is comprises of three dimensions product, environment, and delivery (Rust and Oliver, 1994) or quality delivered through interaction, physical environment and outcome (Lee., 2011). Price is distinguished in to two components, the objective price (the actual prevailing price of a product) and the perceived price (the price as determined by the consumer) (Jacoby and Olson, 1977). Perceived price can be defined as the customer's judgment about an average price in comparison to the price charged by competitors for same product or service (Chen et al., 1994).

Customer satisfaction has often been regarded as a major determinant of loyalty. Customer satisfaction is an overall attitude formed based on the experience after customers purchase a product or use a service (Fornell., 1992). Satisfaction is the assessment of the experience of interacting with a service provider up to the present time, and is used by customers to predict future experience (Crosby et al., 1990). Satisfaction is a broad feeling that is affected by the quality of service and the product, its price and other contextual and personal factors (Zeithaml \& Bitner., 2000).

Trust has been identified as a major driver of loyalty (e.g., Chaudhuri and Holbrook, 2001; Garbarino and Johnson, 1999). A consumer who trusts in a product is more likely to develop favorable attitudes toward it, to pay a premium price for it, to remain loyal to it, and to spread positive word-of-mouth (Chaudhuri and Holbrook., 2001). The impact of trust on customer loyalty becomes especially relevant when confronted with switching decisions with a high level of perceived risk and uncertainty (Lewis, 2002).

Customer loyalty is one of the most important aspects of marketing planning since customer retention is more important than customer absorption (Behara et al., 2002). It is a long term commitment from the existing customers for the repurchase of products and services (Martensen et al., 2007). Customer loyalty is termed as a sustainable source for generation of income while on the other hand, loyal customers are considered as the best people for marketing of products and services (Andreasen \& Lindestad., 1998).

\section{Literature Review}

\subsection{Service Quality}

Service quality's goal is to meet the criteria set by customers thereby leading to customer satisfaction as a consequence. Service Quality is measured through five factors: i) empathy ii) responsiveness, iii) reliability, iv) assurance, v) tangibility' (Parasuraman et al., 1988). Service quality has many aspects one of which includes physical environment (Brady \& Cronin., 2001). Interaction quality forms attitude, performance, and capability. Physical 
environment includes uncontrolled conditions, social factors and design of product. Outcome quality embraces waiting time, tangibles, and valence. All these factors contribute for customer satisfaction.

Service quality is a multifaceted construct which has multiple scopes. To validate these scopes, many researches have been carried out during the last twenty five years (Lee, 2010a). Specifically, Grönroos's (1984) two-dimensional model which classifies quality into two distinct categories mentioned below:

1) Technical quality refers to what is delivered to the customer, and

2) Functional quality is how any particular service is delivered.

The Parasuraman scale implicated expectations-perceptions gap scores evaluated on dimensions as reliability of the product design, customer responsiveness, quality assurance, and customer empathy and product tangibles. (Metters et al., 2003). Later, Parasuraman (1988) described perceived service quality as "The consumer's perception of a product's brilliance and its design quality," thereby verifying the model. Several researches in multiple industry sectors were carried out by Parasuraman et al. (1985) to elaborate SERVQUAL, a multi-item statistical measure to quantify customers' global evaluation of a company's service quality. However, Cronin and Taylor (1992) and Teas (1993) postulated that actual operations and performance related measures as perceived quality are better as compared to perceptual measures. As Maiali et al (2011) put it, service quality is what the consumers ask for, whether it is right or wrong. Thus we may say that previous studies have highlighted the fact that service quality is more of an attitude but can not be considered at par with satisfaction, which is ordinarily expected as an outcome of the comparison between expectations and performance. It is not crucial that customers purchase the product or service which offers highest quality, rather they may rank companies on other attributes as durability, comfort, competitive pricing and even their individual past experiences (Bolton and Drew., 1991; Lee, 2010).

\subsection{Customer Satisfaction}

Customer satisfaction is exhibited by repurchase behavior. It entails fulfillment of primary needs of the customers associated with the product (Guzzo., 2010). Zeithaml and Bitner (2000) defined customer satisfaction as customer's response to the services he receives in relation to fulfillment of his desires and expectations. Customer satisfaction is defined as delivering required service to customers that may generate a positive attitude towards a particular brand used (Maiyaki et al. 2011; Rizwan et al., 2013). According to Fornell (1992), Customer satisfaction is customer stance after usage of a particular product.

In this sense, satisfaction can be thought of as a judgment that "a feature or sometimes product or service itself, provides a delightful level of consumption-related fulfillment." It can be tallied by the retained response of customers. Thus for service providers it is quite evocative to comprehend the degree of customer insight in the services that they offer. 
It is evident from previous literature that there has been much debate as to whether service quality postulates are precedents of customer satisfaction (Parasuraman 1994, Zeithaml 1996). Service quality does contribute a lot to enhance customer satisfaction (Levesque and McDougall, 1996; McDougall and Levesque, 2000). For example, Cronin and Taylor's (1992) SERVPERF model validates the theoretical framework where service quality and customer satisfaction are assumed to have a causal relationship. Jamal and Naser (2002) ascertained that the pivotal dimensions of quality in banking services were positively related to customer satisfaction. Moreover, researches made on telecommunication services exhibited that service quality impinges customer satisfaction (Tung, 2004; Kuo et al, 2009; Lee, 2010). Therefore service quality is a precedent in determination of customer satisfaction quotient. Hence we can propose as follows:

H1: Service quality has a significant positive impact on customer satisfaction.

\subsection{Perceived Price}

Perceived Price acts as a moderator between service quality and customer satisfaction. Price is the medium of exchange with may enable us to get a product or a service.' Researchers like Ali et al (2010) posit that 'customers are disinclined to disburse less in order to have satisfaction this implies that low prices are directly associated to high degree of satisfaction and high quality is associated with higher customer satisfaction. Satisfied customer would have more price forbearance.'

According to Jacoby and Olson, 'Price is of two kinds objective price (the actual price of a product) and perceived price (the price as encoded by the consumer).' This distinction accentuates that the perceived price customers may iterate may not be the real monetary price. As per Butt (2011), 'Price is one of those elements that can entice or repulse customers. Perceived price is actually a qualitative estimate by the customer regarding competitive price for same product or service (Chen et al, 1994). As per chen, 'Perceived price converges on customers' competitive perception as to if they are over charged for the same product or service.' Zeithaml (1988) was firm that 'consumer Understanding of value is more of a conceptual comparison of price and its dimensions'. The National Council of the Green Consumers Network (2012) reported that 'many customers of cell phone companies were mobile phone subscribers who were not satisfied with the extent of hidden and explicit service charges imposed'.

Ryu and Han (2010) found that the 'perceived price has a significant effect on the relationship between quality and customer satisfaction.' Zeithaml (1988) also outlined the constituents of price as 'i) objective price, ii) perceived non-monetary price, and iii) sacrifice. Studies conducted by the author show that the monetary prices of products are not readily recalled by the customers, however they adopt different other means that are meaningful to them for sake of comparison. Therefore we may not be mistaken to make a conjecture regarding customers' perception of a reasonable price, stipulating that it in fact enhances the impact of service quality on customer satisfaction thereby acting as a moderating variable. Thus Hypothesis 2 can be proposed as follows: 
H2: Perceived price has a significant influence on the relationship between service quality and customer satisfaction.

\subsection{Customer loyalty}

Customer loyalty is a firm commitment to repeat encouragement from a chosen product/service consistently, thereby resulting in repetitive purchasing of the same-brand or same brand-set, even though there may be certain situational influences strategic initiatives may that may result in brand replacement and switching. Customer loyalty is an essential component for a brand's long-term viability (1991, Krishnamurthi ). According to Oliver (Oliver, R. L. 1997) Customer loyalty can elaborate customer retention phenomenon best as the likelihood of a customer making repeat purchases, referrals, references and providing positive word-of-mouth publicity (Bowen, J. T. and Shoemaker, S., 1998; ). It helps a company in facing many unprecedented problems in a strong competitive market. According to Uncles et al, '...customer loyalty can be classified as (a) attitudinal-loyalty where the customers owing to their pre-determined perception of a certain brand, (b) behavioral-loyalty to the brand where loyalty to a certain brand emerges as a consequence of past purchase experiences related to use of that brand or service, and (c) co-determinants of buying brand where loyalty is hampered or enhanced by the present state of individuals or the concurrent situation. 'Customer satisfaction may also have a positive effect on customer loyalty' (Deng et al., 2009). Cronin also seems to support the postulate that 'favorable behavioral intentions influence the ability of service providers to retain its present clientele as well as to attract new customer base'. (Cronin and Taylor, 1992; Zeithaml et al., 1996).

Satisfaction is the assessment of the experience of interacting with a service provider up to the present time, and is used by customers to predict future experience (Crosby 1990). 'Satisfaction positively affects customer loyalty' ( Deng, Lu, Wei, \& Zhang, 2009). Though customer satisfaction may not be the sole reason for people to remain loyal to a specific brand (Gerpott, Rams, \& Schindler, 2001), it is safe to say that satisfied customers are more loyal. Thus we can propose $\mathrm{H} 3$ as:

H3: Customer satisfaction has a significant positive impact on customer loyalty.

\subsection{Trust}

According to Errol the level of someone's confidence in another party's capability and his/her performance based on expected ethical principles is defined as trust. (Errol et al., 2005). Believe of one party that other party will fulfill his/her need is known as Trust. It has been discussed broadly in literature. (Errol et al., 2005)]. Trust lead to long-term loyalty and relationship between two parties becomes stronger (Singh \& Sirdeshmukh, 2000).

According to Rauyruen and Miller (2007), there two level of trust. Customer's trust on one specific sales representative is at first level. Whereas trust on institution is at second level. If trust exists, than it is obvious that person is likely to purchase something.

In between buyer-seller transaction, trust acts as a catalyst and in terms of satisfying 
exchange relationship trust provides buyers with higher expectations [J. M. Hawes, E. M. Kenneth, and J. E. Swan, 1989]. One's expectation of dependable and ethical behavior from other party is a trust, Moreover, commitment in business relationships are fulfilled by trusted parties [D. Gefen, E. Karahanna, and D. W. Straub, 2003According to many reseachers, To understand interpersonal behavior in economic exchanges, and benefits from the interaction one must understand Trust. [S. Ba and P. A. Pavlou,2002, P. M. Doney and P. Cannon, 1997]. Customer's belief on trust in terms of service is the delivery of quality services that meets customer's expectations. (Anderson\&Weitz, 1989). According to Herbig (1994), corporates reputation is stability of its activities over time. Trust has the highest importance in assessing the quality of products and services from customers' viewpoint as reputation originates from the quality of its products and services. (Paul et al., 2009). During all the processes, such as changing service, signing up for service and customer support, customer's trust remains as a whole so we can propose $\mathrm{H} 4$ as:

H4: Service quality has a significant positive influence on trust.

According to Palvia (2009), Trust has been abstracted as the antecedent of satisfaction. In between buyer-seller transaction, trust acts as a catalyst and in terms of satisfying exchange relationship trust provides buyers with higher expectations [E. M. Kenneth, and J. E. Swan, 1989]. Higher the customer satisfaction higher the trust. So we can propose H5 as:

H5: Customer satisfaction has a significant positive influence on trust.

In terms of loyalty, trust is a special psychological state that can only happen in certain relationships. As compared to other variables, Trust has a strong impact on purchase intention as compared to other variables according to previous studies. A person is confident of product and service quality of an organization if he/she trusts that organization. Customers are believed to be more loyal to that company if he has trust on it. (Garbarino \& Johnson, 1999). In Chinese mobile instant message users, it was found that trust leads to customer loyalty (Deng et al., 2009). Major driver of customer loyalty is trust (e.g., Chaudhuri and Holbrook, 2001; Garbarino and Johnson, 1999), and according to Reichheld and Schefter (2000) trust is customer loyalty's precondition. ). Those customers happen to be more loyal to company who trusts an organization (Garbarino \& Johnson, 1999). Consumer's trust in a product is more likely to develop an encouraging attitude toward it, to pay a premium price for it, to stay loyal to it, and to spread positive word-of-mouth (Chaudhuri and Holbrook, 2001 Thus we can propose H6 as:

H6: Trust has a positive significant influence on customer loyalty. 


\section{Model}

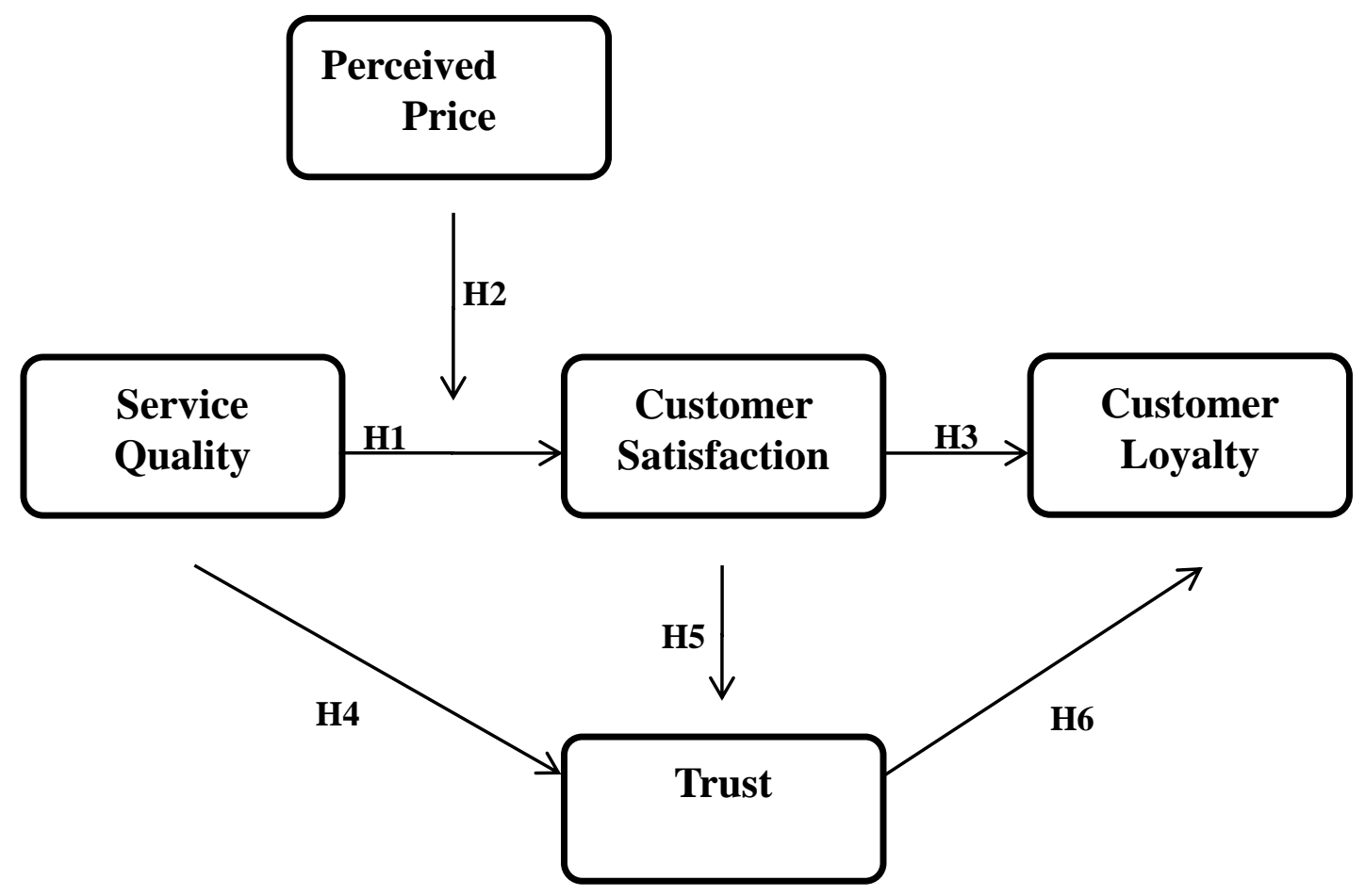

Figure 1: Hypothetical model for current research

\section{Research Methodology}

In table no.3, The Operational Definition and measurements of variables for approval are represented. Preliminary survey was arranged with researchers and marketing specialists from the mobile telecommunication services industry and variables were settled by using the results of these surveys. This survey used the five-point Likert scale for ranking the selected variables. (1: strongly agree to 5: strongly disagree).

\subsection{Sample/Data}

In this survey, the sample was selected from the current users of mobile telecommunication services in Pakistan. An initial survey was administered to revise and complement survey questions.

A total of 200 questionnaires were distributed. After excluding those with omissions or with randomly repeated answers, there were a total of 160 valid survey responses among completed survey forms, excluding those with omissions or with randomly repeated answers. 


\section{Macrothink}

SPSS 16.0 was used for basic statistical analysis, factor analysis and reliability analysis. The population for current research is internet users in Pakistan.

\subsection{Instrument and measures}

The survey instrument explains two main purposes of this study: First purpose is to examine the link of different variables towards customer loyalty.

Second is to collect information about the different attributes of the respondents that can be used to understand the variations in different groups.

The survey instrument consists of two sections. Different personal and demographic variables are involved in section 1. The main purpose of this section is to obtain the respondents information about gender, age, income, education, status and the mobile company he/she is currently using.

Section 2 includes the latent variables that are essential for the study. These variables include Service quality, Customer satisfaction, perceived price (as a moderator between customer service quality and customer satisfaction) trust and customer loyalty.

The scales used in this study are adopted from preceding literature and published studies. The variables, items and their references are given in Table no. 1.

Table 1: Scales of the study

\begin{tabular}{|c|c|c|c|}
\hline No. & Variable & Items & References \\
\hline 1 & $\begin{array}{l}\text { Customer } \\
\text { Loyalty }\end{array}$ & $\begin{array}{l}\text { 1. My Mobile service would be my first } \\
\text { choice. } \\
\text { 2. I consider myself to be loyal to my mobile } \\
\text { service. } \\
\text { 3. I recommend this mobile service to } \\
\text { someone who seeks my advice. } \\
\text { 4. I get good value for my money. } \\
\text { 5. I say positive things about my mobile } \\
\text { service to other people. } \\
\text { 6. I consider the service I am using my first } \\
\text { choice in the next few years. }\end{array}$ & $\begin{array}{l}\text { Chaudhuri } \\
\text { and } \\
\text { Holbrook, } \\
2001\end{array}$ \\
\hline 2 & $\begin{array}{l}\text { Customer } \\
\text { Satisfaction }\end{array}$ & $\begin{array}{l}\text { 1. Overall I am satisfied with the specific } \\
\text { experience I have so far with the mobile }\end{array}$ & $\begin{array}{l}\text { Ragunathan } \\
\text { and }\end{array}$ \\
\hline
\end{tabular}




\begin{tabular}{|c|c|c|c|}
\hline & & $\begin{array}{l}\text { service I am using. } \\
\text { 2. . I am satisfied with my decision to } \\
\text { purchase from this company. }\end{array}$ & Irwin(2001) \\
\hline 3 & Trust & $\begin{array}{l}\text { 1. I trust on my mobile service. } \\
\text { 2. I rely on my mobile service. } \\
\text { 3. The mobile service I am currently using } \\
\text { works on the principle of honesty. } \\
\text { 4. My mobile service meets my expectations. } \\
\text { 5. The mobile service I am using is safe. }\end{array}$ & $\begin{array}{l}\text { Chaudhuri } \\
\text { and } \\
\text { Holbrook, } \\
2001\end{array}$ \\
\hline 4 & Service quality & $\begin{array}{l}\text { 1. My mobile service is of high quality. } \\
\text { 2. It is likely that the mobile service I am } \\
\text { using is very high quality. } \\
\text { 3. It is likely that the mobile service is of very } \\
\text { consistent quality. } \\
\text { 4. It is likely that the mobile service offers } \\
\text { excellent features. }\end{array}$ & $\begin{array}{l}\text { Chaudhuri } \\
\text { and } \\
\text { Holbrook, } \\
2001\end{array}$ \\
\hline 5 & $\begin{array}{l}\text { Perceived } \\
\text { Price }\end{array}$ & $\begin{array}{l}\text { 1. I consider the company's pricing } \\
\text { policy as fair. } \\
\text { 2. I consider the company's pricing } \\
\text { policy as ethical. } \\
\text { 3. I consider the company's pricing policy } \\
\text { as acceptable } \\
\text { 4. I paid a fair price for the mobile service } \\
\text { I am using. }\end{array}$ & $\begin{array}{l}\text { Yoo et al } \\
(2000)\end{array}$ \\
\hline
\end{tabular}

\subsection{Procedure}

The questionnaire was distributed among 200 respondents who were selected on the basis of above mentioned criteria. The purpose of study and questions were explained to the 
respondents before giving the questionnaires so that it becomes easy for them to fill the questionnaire with relevant responses. A total of 160 questionnaires were selected, others were discarded due to incomplete or irrelevant responses. After collecting the responses, these questionnaires were coded and entered into SPSS sheet for further analysis.

\subsection{Reliability Analysis}

Overall the values of Cronbach's alpha of all research variables were is more than the acceptable and recommended value of 0.50 by Nunnally (1970) and 0.60 by Moss et al. (1998). This shows that all the 21 selected items were reliable and valid to measure the views of consumers towards customer loyalty.

Table 2 : Reliability of measuring instrument

\begin{tabular}{|l|l|l|}
\hline Scales & Items & Cronbach's Alpha \\
\hline Customer loyalty & 6 & 0.876 \\
Customer satisfaction & 2 & 0.782 \\
Trust & 5 & 0.856 \\
Service quality & 4 & 0.860 \\
Perceived price & 4 & 0.813 \\
\hline
\end{tabular}

\section{Results}

\subsection{Profile of respondents}

Following table contains demographic information of the respondents such as gender, age, income, status and the mobile company.

Table 3: Profile of the Respondents

\begin{tabular}{|l|l|l|l|}
\hline Variable & Category & Frequency & Percentage \\
\hline Gender & Male & 58 & 36.3 \\
& Female & 102 & 63.8 \\
\hline Age & Below 20 & 65 & 40.6 \\
\hline
\end{tabular}




\begin{tabular}{|c|c|c|c|}
\hline & $\begin{array}{l}20-30 \\
30-40 \\
\text { Above } 40\end{array}$ & $\begin{array}{l}82 \\
9 \\
4\end{array}$ & $\begin{array}{l}51.3 \\
5.6 \\
2.5\end{array}$ \\
\hline Income & $\begin{array}{l}\text { Below } 10000 \\
10000-20000 \\
20000-30000 \\
30000-40000 \\
\text { Above } 40000\end{array}$ & $\begin{array}{l}124 \\
13 \\
7 \\
7 \\
9\end{array}$ & $\begin{array}{l}77.5 \\
8.1 \\
4.4 \\
4.4 \\
5.6\end{array}$ \\
\hline Status & $\begin{array}{l}\text { Student } \\
\text { Employed } \\
\text { Unemployed } \\
\text { Self employed }\end{array}$ & $\begin{array}{l}140 \\
16 \\
1 \\
3\end{array}$ & $\begin{array}{l}87.5 \\
10 \\
.6 \\
1.9\end{array}$ \\
\hline $\begin{array}{l}\text { Mobile } \quad \text { service } \\
\text { provider }\end{array}$ & $\begin{array}{l}\text { Telenor } \\
\text { Mobilink } \\
\text { Ufone } \\
\text { Warid } \\
\text { Zong }\end{array}$ & $\begin{array}{l}27 \\
54 \\
55 \\
12 \\
12\end{array}$ & $\begin{array}{l}16.9 \\
33.8 \\
34.4 \\
7.5 \\
7.5\end{array}$ \\
\hline
\end{tabular}

\subsection{Hypothesis testing}

\section{Service Quality, Customer Satisfaction and Customer Loyalty}

According to the results of the study, Service Quality has a significant positive relationship with Customer satisfaction with $(\beta=.643)$ and $(p=0.000)$. That means the Service Quality contribute more than $64 \%$ towards customer satisfaction.

The regression results of customer satisfaction with Customer loyalty is also significant with $(\beta=0.457)$ and $(\mathrm{p}=0.000)$.

Results of the current study validate the $\mathrm{H} 1$ and $\mathrm{H} 3$. 


\section{Macrothink}

\section{Service Quality and Customer Satisfaction towards Trust}

The regression results of the study confirm the significant positive relationship between Service Quality and trust with $(\beta=0.435)$ and $(\mathrm{p}=0.00)$. According to these results, Service Quality contributes more than $43 \%$ towards trust. Results also shows a significant positive relationship between customer satisfaction and trust with $(\beta=0.401)$ and $(p=0.00)$. It means Customer satisfaction contributes more than $40 \%$ towards trust.

This validates $\mathrm{H} 4 \mathrm{and} \mathrm{H} 5$.

\section{Trust and Customer Loyalty}

Regression Analysis of the study shows that there is a significant positive relationship between Trust and Customer Loyalty with $(\beta=0.379)$ and $(\mathrm{p}=0.00)$. According to this result, trust contributes more than $37 \%$ towards customer loyalty.

The results of the study support H6.

\section{Perceived Price as Moderator}

Study's Regression analysis approves the moderation of perceived price between the relationship of service quality and customer satisfaction. The impact of perceived price and service quality were significant (Beta $=0.380$ and sig $=0.000$ and Beta $=0.413$ and sig $=0.000$ respectively) on customer satisfaction also the interaction term (service quality $\mathrm{x}$ perceived price) is significant with $\mathrm{B}=0.095$ and sig $=0.027$.

Table 4: Regression Results

\begin{tabular}{|l|l|l|l|l|l|l|}
\hline Hypothesis & $\begin{array}{l}\text { Model } \\
\text { Variables }\end{array}$ & Estimate & S.E & C.R. & P & Results \\
\hline H1 & $\begin{array}{l}\text { SQ } \\
\text { CS }\end{array}$ & .643 & .056 & 5.262 & 0.00 & Supported \\
\hline H3 & $\begin{array}{l}\text { CS } \\
\text { CL }\end{array}$ & .457 & .072 & 6.553 & 0.00 & Supported \\
\hline H4 & $\begin{array}{l}\text { SQ } \\
\text { Trust }\end{array}$ & .435 & .059 & 6.411 & 0.00 & Supported \\
\hline H5 & $\begin{array}{l}\text { CS } \\
\text { Trust }\end{array}$ & .401 & .064 & 5.905 & 0.00 & Supported \\
\hline H6 & $\begin{array}{l}\text { Trust } \\
\text { CL }\end{array}$ & .379 & .076 & 5.435 & 0.00 & Supported \\
\hline
\end{tabular}


Figure 2: Structural model results

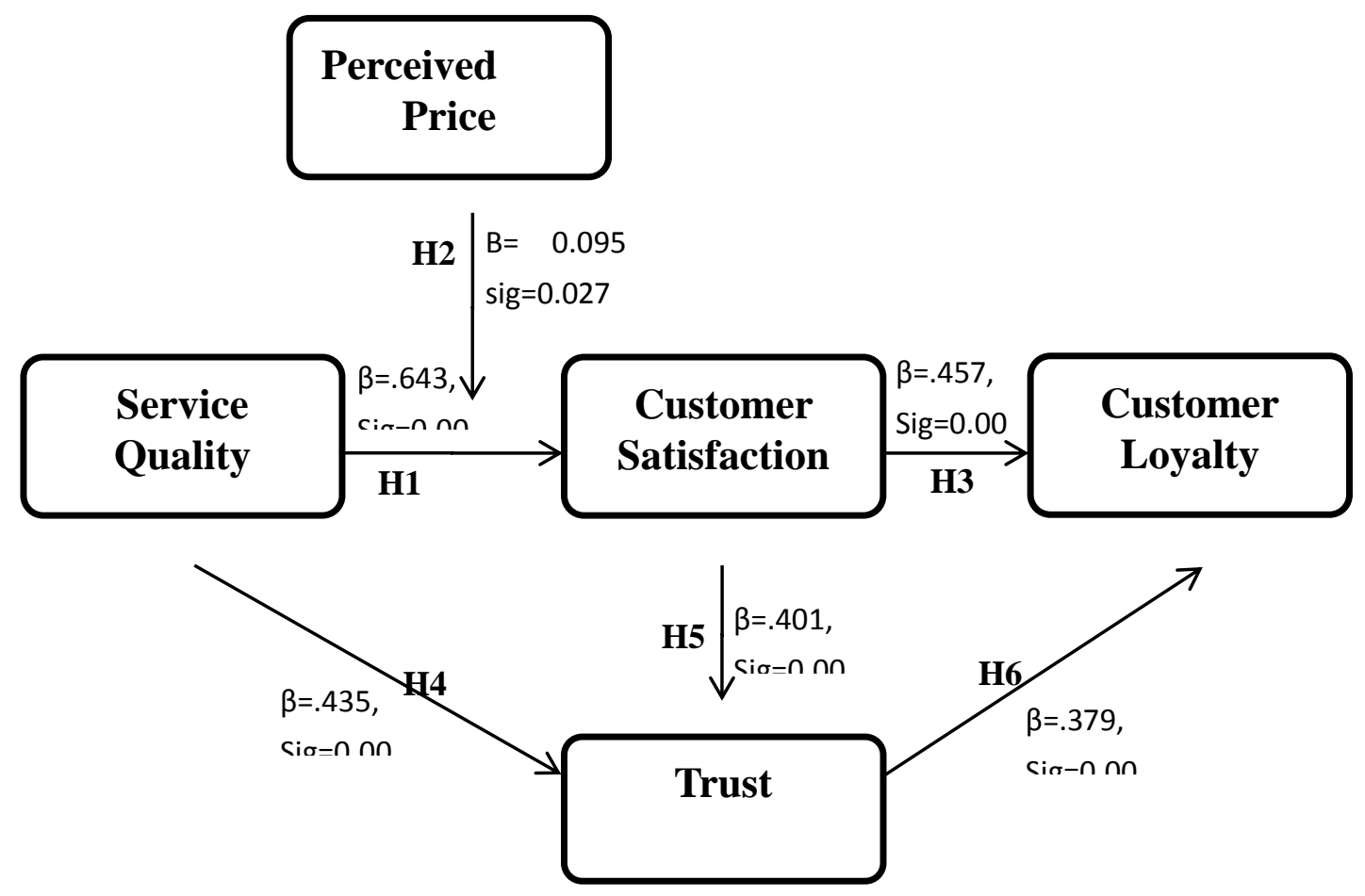

\section{Discussion}

This study examines the extent to which mobile users are Loyal to the mobile service they are using. Researchers are aware of the fact that the biggest challenge for telecommunication companies is customer retention. Mobile users keep changing their mobile service providers. This study helps determine what factors affect the intentions of the user to stay loyal to the company they have hired as the service provider. This study has important implications for practice. With the advent of increasing competition for greater market share within the telecommunication industry of Pakistan, unique core competencies and inimitable competitive advantages are imperative for success in this highly dynamic sector. One of the best and profound ways of achieving this is through a cogent marketing and customer retention strategy. The investment that an organization takes up to attract new customers is significantly higher than the costs of retaining the old clientele base. Therefore, the key focus in the process of achieving customer satisfaction is to identify and deploy the core satisfaction determinants from the user's standpoint and then to evaluate the process by which the company addresses all those concerns. Most taxing and challenging job that brands face is image management with the objective of customer satisfaction. They must endeavor to improve product attributes, enhance service quality and built trust to improve customer's experiences with mobile telecommunication devices and by doing so get a hiked in customer loyalty.

The results of this study revealed that service quality has a significant positive impact on 
customer satisfaction with perceived price acting as a moderator between the two variables. Mobile users are highly satisfied from the service quality if the actual price they pay for the service is less than or equal to the perceived price. This is the strongest link relative to other links shown in the model. Results verify the research model link H1 that higher degree of service quality will consequently lead to higher level of customer satisfaction and a loyal clientele. The primary reason for this is customer perception of being in receipt of better quality and competitive price oriented services thereby deriving maximum value by paying low price for a better telecommunications service. Moreover, when customer satisfaction is built onto the link between service quality and customer loyalty, it starts playing the role of a moderator and mediator, impinging the relationship between service quality and customer loyalty, strengthening the ties. Previous studies have exhibited the importance of customer satisfaction and its effect on customer loyalty (Woo and Fock, 1999; Lee, 2010a, 2010b). According to the research findings of Woo, 'Customer satisfaction was found to be a key factor in the relationship between customers and service providers'. If the customers are satisfied it is most likely that they will be loyal to the brand they are using. The link shown between customer satisfaction and customer loyalty is significantly positive and relatively strong too. Hypothesis proposing that good service quality helps gain the customer's trust is also supported through the findings. Results indicate that trust significantly effects customer loyalty. If the customer feels safe in using the mobile service it is less likely that he will switch to another mobile company. Therefore it could be said that all links shown in the model of this study are supported.

Research stipulates that telecom sector needs to incorporate technological innovations as per product and process, provide customer friendly ancillary services in order to satisfy the existing customer base and to attract new clientele. These findings are also consistent with the research work of Khokhar et al. (2011) proving that service quality, competitive prices and satisfaction of customer will ultimately lead to a loyal customer base. Acquiring new customer's costs five times more than retaining the old customers.

Therefore this study could be used as a guide for telecommunication companies in Pakistan to keep their focus on the variables affecting customer loyalty. The most valuable relationship explained is customer satisfaction to customer loyalty. Satisfied customer serves as the best advertisement; this study not only discusses the variables influencing customer loyalty but also the impact of service quality and trust over customer satisfaction.

\section{Limitations and Future Research}

Although this research has taken vital steps to identify the factors that influence Customer satisfaction and customer loyalty, it also has certain limitations. Firstly, the limitation of the data prevents further exploration of the study. Only 160 respondents have contributed in this research. These respondents were practically similar in age and other demographics since most of them were between 18 to 25 years old therefore represented early adulthood only. By the difference in the ages of the respondents, different results could be generated.

Secondly, upcoming researchers have more opportunity to carry out their research in improved situations and at various geographic localities. We have conducted this research on 
customer loyalty in telecommunication sector of Pakistan in Bahawalpur. Diverse environment always plays a positive role that helps affect the respondent's behavior. Since this study was conducted in Islamia university of Bahawalpur and different area of Bahawalpur Pakistan, it could not represent other people living in urban or rural areas where the quality of life is totally different. Finally, it is recommended for the future researchers that they explore perceived price and its moderating influence on the relationship between service quality and customer satisfaction.

\section{References}

Parasuraman, A., Zeithaml, V. A., \& Berry, L. L. (1988). SERVQUAL: a multiple-item scale for measuring consumer perceptions of service quality. Journal of Retailing, 64(Spring), 2-40.

Parasuraman, A., Zeithaml, V. A., \& Berry, L. L. (1994). Reassessment of expectations as a comparison standard in measuring service quality: implications for further research. Journal of Marketing, 58(January),

Cronin, J. J., \& Taylor, S. A. (1992). Measuring service quality: A re-examination and extension. Journal of Marketing, 56(3), 55-68.

Cronin, J. J., Brady, M. K., \& Hult, G. T. M. (2000). Assessing the effects of quality, value and customer satisfaction on consumer behavioral intentions in service environment. Journal of Retailing, 76(2), 193-218.

Lee, C. C. (2009). Analysis of overall technical efficiency, pure technical efficiency and scale efficiency in the medium-sized audit firms. Expert Systems with Applications, 36, 11156-11171.

Lee, S., Lee, K., \& Kang, I. W. (2005). Efficiency analysis of controls in EDI applications. Information and Management, 42, 425-439.

Metters, R., King-Metters, K., \& Pullman, M. (2003). Successful Service Operations Management. Thomson South-Western.

Guzzo, R., 2010. Customer satisfaction in the hotel industry: A case study from sicily. Int. J. Market. Stud., 2(2): 3-12.

Fornell, C., 1992. A national customer satisfaction barometer: the Swedish experience. JournalofMarketing56,6-21.

Cronin, J.J., Taylor, S.A., 1992. Measuring service quality: a reexamination and extension. Journal of Marketing 56 (July), 55-68.

Taylor, S. A., \& Baker, T. L. (1994). An assessment of the relationship between service quality and customer satisfaction in the formation of customers' purchase intentions. Journal of Marketing, 58(Summer), 163-178.

McDougall, G.H.G., Levesque, T., 2000. Customer satisfaction with services: putting perceived value into the equation. Journal of Services Marketing 14 (5), 392-410. 


\section{MInstitute Macrothink $_{\text {Int }}$}

Levesque, T., \& McDougall, G. H. G. (1996). Determinants of customer satisfaction in retail banking.

\section{Zeithaml (Ed.), Review of Marketing (pp. 68-123).}

C.-R. Kim, and E. J. Lee, "Impact of website information design factors on consumer ratings of web-based auction sites," Behaviour \& Information Technology, vol. 21, pp.

Tung, L.L., Tan, P. L.J., Chia, P.J.T., Koh, Y.L., and Yeo, H.L. (2001), "An empirical investigation of virtual communities and trust", Proceedings of Twenty-Second International Conference on Information Systems, pp. 307- 319.

Turel, O., \& Serenko, A. (2006). Satisfaction with mobile services in Canada:An empirical investigation. Telecommunications Policy, 30(5/6), 314-331.

Kuo, Y., Wu, C., \& Deng, W. (2009). The relationships among service quality, perceived value, customer satisfaction, and post-purchase intention in mobile value-added services. Computers in Human Behavior, 25, 887-896.

Butt, H.S., 2011. Measuring customer satisfaction w.r.t restaurant industry in Bahawalpur.

Ali, 2010. Effects of corporate social responsibility on consumer retention in cellular industry of Pakistan.

Jacoby, J., \& Olson, J. C. (1977). Customer response to price: an attitudinal, information processing perspective.

Ryu, K., \& Han, H. (2010). Influence of the quality of food, service, and physical environment on customer satisfaction and behavioral intention in quick-casual restaurants: moderating role of perceived price.

Krishnamurthi, L. and Raj, S.P. (1991). A Empirical Analysis of The Relationship Between Brand Loyalty And Consumer Price Elasticity. Marketing Sccience, 10 (2), 172-83.

Oliver, R. L. (1997). Satisfaction: A Behavioral Perspective on the Customer. New York: McGraw-Hill.

Bowen, J. T. and Shoemaker, S. (1998). Loyalty: A Strategic Commitment? Cornel Hotel and Restaurant Administration Quarterly, 1225.

Pritchard, M.P. and Howard, D. R. (1997). The Loyal Traveler: Examining a Typology of Service Patronage. Journal of Travelers Research, 35 (4), 2-11.

Rizwan, M., Riaz, T., Akhter, N., Murtaza, G., Hasnain, M., Hussain, L. \& Rasheed, I. (2013) Antecedents of Brand Loyalty an Empirical Study from Pakistan, International Journal of Research in Computer Applications and Management, 3(3), 165-171

Deng, Z., Lu, Y., Wei, K. K., \& Zhang, J. (2009). Understanding customer satisfaction and loyalty: an empirical study of mobile instant messages in China. International Journal of Information Management, article in press. 
de Ruyter, K., \& Wetzels, M. G. M. (2000). The impact of perceived listening behavior in voice-to-voice service encounters. Journal of Service Research, 2(3), 276-284.

Deng, Z., Lu, Y., Wei, K. K., \& Zhang, J. (2009). Understanding customer satisfaction and loyalty: An empirical study of mobile instant messages in China. International Journal of Information Management, doi:10.1016/j.ijinfomgt.2009.10.001.

Dick, A. S., \& Basu, K. (1994). Customer loyalty: Toward an integrated conceptual framework. Journal of the Academy of Marketing Science, 22(2), 99-113

Gerpott, T. J., Rams, W., \& Schindler, A. (2001). Customer retention, loyalty and satisfaction in the German mobile cellular telecommunications market. Telecommunications Policy, 25(4), 249-269.

Rauyruen, P., \& Miller, K. E. (2007). Relationship quality as a predictor of B2B customer loyalty. Journal of Business Research, 60(1), 21-31.

Singh, J.,\&Sirdeshmukh, D. (2000). Agency and trust mechanisms in consumer satisfaction and loyalty judgments. Journal of the Academy of Marketing Science, 28(1), 150-167.

D. Gefen, E. Karahanna, and D. W. Straub, "Trust and TAM in online shopping: An integrated model," MIS Quarterly, vol. 27, pp. 51-90, 2003.

Hawes, E. M. Kenneth, and J. E. Swan, "Trust Earning Perceptions of Sellers and Buyers," Journal of Personal Selling and Sales Management, vol. 9, pp. 1-8, 1989.

$\mathrm{Ba}$ and P. A. Pavlou, "Evidence of the effect of trust building technology in electronic markets: Price premiums and buyer behavior," MIS Quarterly, vol. 26, pp. 243-268, 2002.

P. M. Doney and P. Cannon, "An Examination of the Nature of Trust in Buyer-Seller Relationships," Journal of Marketing Research, vol. 61, pp. 35-51, 1997.

Anderson, E., \&Weitz, B. (1989). Determinants of continuity in conventional industrial channel dyads. Marketing Science, 8(3), 10-23.

Palvia, P. (2009). The role of trust in e-commerce relational exchange: A unified model. Information \& Management, 46(4), 213-220.

Garbarino, E., Johnson, M.S., 1999. The different roles of satisfaction, trust and commitment in customer relationships. Journal of Marketing 63 (April), 70-87.

Reichheld, F.F., \& Schefter, P. (2000). E-loyalty: Your secret weapon on the Web. Harvard Business Review, 78(4), 105-114.

Chaudhuri, A.,Holbrook,M.B.,2001.Thechainofeffectsfrombrandtrustand brand affect to brand performance: the role of brand loyalty. Journal of Marketing 65(2),81-93.

Lee, H. S. (2010a). Effects of perceived value and service quality on customer satisfaction in the mobile phone service market. INFORMATION: An International Interdisciplinary Journal, 13(4), 1207-1218. 


\section{Macrothink}

Journal of Sociological Research

ISSN 1948-5468

2014, Vol. 5, No. 1

Rizwan, M., Usman, A., Hussain, T., Shafiq, A., Rauf, S. \& Ayaz, Q., (2013) The Impact of the Perceived Quality, Customer Satisfaction, Brand Trust and Contextual Factors on Brand Loyalty, International Journal of Research in Commerce and Management, 4(3), 83-89

Lee, H. S. (2010b). Factors influencing customer loyalty of mobile phone service: empirical evidence from Koreans. Journal of Internet Banking and Commerce, 15(2), 1-14.

Khokhar, S.Z., F. Hussain, T.M. Qureshi, I. Anjum, A. Samran and R. Arshad, 2011. Only customer satisfaction and customer loyalty is not enough: A study of Pakistan's telecom sector. Afr. J. Bus. Manag., 5(24): 10176-10181. 